neonate. Despite this group of patients theoretically being highly motivated to prevent the spread of the disease five of the 34 pregnancies were complicated by primary infection with the virus. This suggests that all men with genital herpes should be counselled about the need for screening pregnant consorts, and such couples should be advised either to abstain from sexual contact or to use barrier methods of protection from the third trimester until delivery

We recommend that all women with a history of genital infection with herpes simplex virus should be screened during pregnancy.

1 Prober CJ, Sullender WM, Yasukawa LL, Au DS, Yeager AS. Low risk of herpes simplex virus infections in neonates exposed to the virus at the time of vaginal delivery to mothers with rections

2 Arvin AM, Hensleigh PA, Rober CG, Au DS. Failure of antepartum maternal cultures to predict the infant's risk of exposure to herpes simplex virus at delivery. N Engl f Med 1986;315:796-800.
Vontver LA, Hickock DE, Brown Z, Reid L, Corey L. Recurrent genital herpes simplex virus Vontver LA, Hickock DE, Brown $\mathrm{Z}$, Reid $\mathrm{L}$, Corey $\mathrm{L}$. Recurrent genital herpes simplex virus
infection in pregnancy: infant outcome and frequency of asymptomatic recurrences. Am $\mathcal{f}$ Obstet Gynecol 1982;143:75-84.

4 Woodman CBJ, Weaver JB. Virological screening for herpes simplex virus (HSV) in late pregnancy. Lancet 1986;i:744.

5 Binkin NJ, Koplan JP, Cates W. Preventing neonatal herpes: the value of weekly viral cultures in pregnant women with recurrent genital herpes. fAMA 1984;251:2816-21.

(Accepted 9 March 1988)

Department of Genitourinary Medicine, Royal Hallamshire Hospital, Sheffield S10 2JF

P D WOOLLEY, DRCOG, MRCP, senior registrar

C A BOWMAN, MA, MRCP, research registrar

D A HICKS, MB, MRCOG, consultant in genitourinary medicine

G R KINGHORN, MD, MRCP, consultant in genitourinary medicine

Correspondence to: Dr Woolley.

\section{Screening pregnant women for genital herpes}

Neonatal herpes is associated with a high morbidity and high mortality. Nevertheless, only 84 cases were reported in England and Wales between 1981 and $1984 .^{~}{ }^{\prime}$ Most infants in whom infection with herpes simplex virus occurs have acquired the virus from the mother's birth canal during delivery. ${ }^{2}$ The risk to the neonate is greatest if the mother is having her first attack at that time. Caesarean section in those with herpes at term, however, has been shown to prevent neonatal herpes. ${ }^{2}$

In order to detect herpes at term we need to screen women at risk in the obstetric population (those with primary or recurrent herpes and those whose partners have herpes). There is very little information about the use of screening for herpes in pregnancy in the United Kingdom. This study reports on the demographic characteristics, frequency of attacks in pregnancy, and outcome of pregnancy in a group of women who were screened for herpes in pregnancy.

\section{Present study}

In 1984 a screening policy for pregnant women at risk of herpes was established in the department of genitourinary medicine. This consisted of a weekly clinical examination and viral culture from the cervix and vulva from 36 weeks of pregnancy until delivery. If at the time of delivery the previous viral culture had been positive or there was clinical evidence of herpes a caesarean section was recommended. In all other circumstances the pregnancy was handled in accordance with normal obstetric practice.

Between 1984 and 1987,78 women were screened. Their median age was 31 (range 21-41) and 64 were primiparous. One woman had a primary attack at 30 weeks, seven attended because their partners had herpes, and 70 because they were suffering a recurrent attack.

Seventeen of the 62 women with recurrent herpes in whom the outcome of pregnancy was known had a caesarean section because of herpes (table). None of the 25 women without recurrences in pregnancy had a caesarean section compared with six of the 17 with one attack and 11 of the 20 with two or more attacks $(p=0.0003)$.

\section{Comment}

These findings show that over one fifth of women with recurrent genital herpes will have a caesarean section because of their illness. The more frequent the attacks the more likely the woman is to have a caesarean section. With regard to screening, however, there are several drawbacks, including
Characteristics of women screened for herpes in pregnancy

\begin{tabular}{lccc}
\hline & $\begin{array}{c}\text { Primary } \\
\text { herpes } \\
(\mathrm{n}=1)\end{array}$ & $\begin{array}{c}\text { Recurrent } \\
\text { herpes } \\
(\mathrm{n}=70)\end{array}$ & $\begin{array}{c}\text { Herpes in } \\
\text { partner } \\
(\mathrm{n}=7)\end{array}$ \\
\hline $\begin{array}{l}\text { No having no or one attack in year before pregnancy } \\
\text { No having no or one attack during pregnancy }\end{array}$ & 0 & 21 & 0 \\
$\quad$ (excluding delivery) & 1 & 24 & 0 \\
$\begin{array}{l}\text { No with herpes at delivery } \\
\text { Outcome of pregnancy }\end{array}$ & 0 & 13 & 0 \\
$\quad$ Vaginal delivery & 1 & 40 & 7 \\
$\quad$ Caesarean section for obstetric reasons & 0 & 4 & 0 \\
$\quad$ Caesarean section for herpes & 0 & 17 & 0 \\
\hline Miscarriage & 0 & 1 & 0 \\
\hline
\end{tabular}

^Excludes eight women with recurrent herpes in whom outcome unknown.

cost ${ }^{3}$ additional patient visits, the inability to detect all infected patients (viral cultures may take up to a week, not all lesions will be culture positive, and attacks may occur between visits), and the morbidity and mortality associated with caesarean section. Also a substantial proportion of neonates will be born to mothers unaware that they are infected ${ }^{4}$ and who consequently will not be screened.

Is there any alternative approach? Suppressive treatment with acyclovir in late pregnancy may offer some hope. The drug is highly effective in suppressing attacks in patients with recurrent genital herpes. ${ }^{5}$ The efficacy and safety of acyclovir in this setting, however, will need to be assessed in carefully controlled studies.

1 Woodman CBJ, Weaver JB. Virological screening for herpes simplex virus (HSV) in late pregnancy. Lancet 1986; ;:744.

Nahmias AJ, Keyserling HH, Kerrick G. Herpes simplex. In: Remington JS, Klein JO, eds Infectious diseases of the fetus and newborn infant. Philadelphia: W B Saunders, 1983:156-90.

3 Binkin NJ, Koplan JP, Cates W. Preventing neonatal herpes: the value of weekly viral cultures in pregnant women with recurrent genital herpes. FAMA 1984;251:2816-21.

4 Whitley RJ, Nahmias AJ, Visintine AM, Fleming CL, Alford CA. The natural history of herpes simplex virus of mother and newborn. Pediatrics 1980;66:489-94.

Mindel A, Weller IVD, Faherty A, et al. Prophylactic oral acyclovir in recurrent genital herpes. Lancet 1984;ii:57-9.

(Accepted 9 March 1988)

Academic Department of Genitourinary Medicine, Middlesex Hospital,

London WIN 8AA

ORLA CARNEY, RGN, research nurse

ADRIAN MINDEL, MRCP, consultant

Correspondence to: Dr Mindel.

\section{Death from hypothermia: are current views on causative factors well founded?}

Mortality from hypothermia is a sensitive issue and is widely regarded to be associated with poor housing and heating facilities. I assessed the accuracy of this belief by carrying out a retrospective study of computerised inquest records.

\section{Subjects, methods, and results}

Deaths occurring in Sheffield and Barnsley in which hypothermia was a registered factor were analysed for the period 1981-6 in the coroner's district of South Yorkshire East (population 772000 ). There were 43 deaths (mean $7 \cdot 5$ a year), with an equal sex incidence and mean age at death of 73.9 years. Forty deaths occurred during the period December to March. The mean minimum air temperature on the known or estimated day of death was $0.1^{\circ} \mathrm{C}$ and lower than the actual or long term monthly means of $1.6^{\circ} \mathrm{C}$ and $2.5^{\circ} \mathrm{C}$, respectively. In 35 subjects hypothermia was secondary to another disease: dementia (nine), cardiovascular disease (nine), fractures (five), pneumonia (five), thyroid disease (three), gastrointestinal disease (two), schizophrenia (two), or meningioma (one). In five subjects hypothermia was secondary to alcohol or drug overdose.

Fifteen deaths occurred in subjects not living alone, of whom 12 suffered from mental illness. These were all under supervisory care (five in hospital; four at home; three in a nursing home), and in all 12 cases death occurred when the subjects wandered away from the place of supervision. The subjects' bodies were discovered between 25 minutes and 21 days (mean 4.4 days) after their disappearance within a mean radius of 1.6 miles. Bodies were discovered accidentally in five cases, by supervisory parties in four, and by the police in three. Eight subjects had been officially reported as missing. In no case were drugs taken because of the mental illness considered to have contributed to the 
development of the hypothermia. One inquest highlighted poor hospital security arrangements as a causative factor.

Of the 28 subjects living alone, 15 had been visited shortly before death by close relatives (mean $2 \cdot 1$ days) and five by friends or neighbours (mean $2 \cdot 7$ days). Five of the subjects had been visited recently by a representative of at least one of the support services (family practitioner, nurse, home help, or social worker) (mean $2 \cdot 0$ days), and six subjects had been advised by a member of one of the services. All bodies were found by the visiting groups. Eight subjects persistently declined help despite regular supervisory visits. Five deaths were associated with inadequate housing and heating facilities. In 10 cases potentially adequate heating facilities were not being used at the time of death, although in eight of these cases financial resources seemed to be adequate. In two cases self neglect was evident, and these were unknown to the support services.

Nineteen subjects were found sufficiently quickly to allow emergency admission to hospital (mean temperature on admission $29 \cdot 2^{\circ} \mathrm{C}$ ); this included $62 \%$ of those living alone.

\section{Comment}

Though there is a high yearly mortality related to cold weather of around 40000 , this study is in agreement with others that deaths due to hypothermia are rare. ${ }^{1}$

The study shows that $35 \%$ of deaths from hypothermia were associated with housing and heating problems. Though the subjects in this group often received regular visits $(89 \%)$, heating facilities remained inadequate in $18 \%$ of cases and unused in $36 \%$. Lack of use was associated with financial hardship in only $20 \%$ of cases, and concern over potential heating costs thus seems to be a possible explanation for lack of use in the others.

An unexpected finding was another group of fatalities (28\%) that occurred in mentally ill subjects who had wandered away from their place of supervisory care. It is well accepted that mental illness may create a state of unawareness of the cold environment,${ }^{2}$ but the risks of wandering seem to be insufficiently emphasised.

I thank Drs H Pilling and S Popper (HM coroners) for allowing me access to inquest records; and Mr S P Garland and Gaynor Boon, assistant keepers, earth sciences/meteorology, City of Sheffield Museums Department, for providing meteorological data.

1 Anonymous. Deaths in winter. Lancet 1985;ii:987-8

Collins KJ. Temperature regulations and hypothermia in the elderly. Oxford: Oxford University Press, 1983:91-104.

(Accepted 14 March 1988)

Rotherham District General Hospital, Rotherham S60 2UD

D N SLATER, BMEDSCI, MRCPATH, consultant histopathologist

\section{Occurrence of different ensuing triggering infections preceding reactive arthritis: a follow up study}

An ever increasing variety of microbes has been reported to trigger reactive arthritis, especially in patients with HLA-B27.' Interestingly, the possible occurrence of a different ensuing triggering infection in a patient previously cured of joint inflammation has not been studied, presumably because these patients are few and treated in different medical centres on different occasions.

\section{Patients, methods, and results}

The five patients in this series were considered to have typical reactive arthritis by virtue of the clinical picture and specific microbiological and serological results (table). All patients were positive for HLA-B27 but none had a family history of ankylosing spondylitis or rheumatoid arthritis. Tests made to identify the causative infectious agent included cultures from urethral secretions, throat, and faeces; agglutination tests for yersinia, salmonella, shigella, and group A streptococcal antigens; enzyme immunoassay for Chlamydia trachomatis and campylobacter; and a complement binding test for Neisseria gonorrhoeae. Antistreptolysin $\mathrm{O}$, antistaphylolysin, and teichoic acid antibodies were measured by radioimmunoassay. Routine viral antibodies were assayed by using complement fixation. Patients were tested for rheumatoid factor and antinuclear antibodies. Gout and purulent arthritis were also excluded.

The interval between the initial episode of reactive arthritis and the ensuing relapse varied between 1.5 and 11 years, during which patients were free of symptoms in the joints. In two patients the titres of the initial triggering infections were not available, but the diagnosis was adequately verified by a physician (table). All patients showed typical signs of monoarthritis, oligoarthritis, or polyarthritis. In four patients the second episode of arthritis affected several joints. Only two patients, however, had radiological evidence of erosions. These two patients were considered to have a chronic Reiter type of disease, including both extra-articular manifestations and permanent bone erosions. Afte the relapse and because of the chronic nature of the arthritis three patients (cases 1-3) were treated with antirheumatic drugs; the other two patients received only symptomatic treatment.

\section{Comment}

Reactive arthritis often consists of a seronegative asymmetric arthropathy beginning one to three weeks after a triggering infection. It may show additional features compatible with Reiter's syndrome, but whereas Reiter's syndrome is often a chronic disease, reactive arthritis has a tendency to heal. In most cases reactive arthritis is preceded by an enteric or venereal infection and closely related to the major histocompatibility complex locus I, coded HLA-B27.

Recent reports have suggested that exogenous antigens and specific HLA molecules together with an activated immune response are responsible for the joint inflammation in reactive arthritis. Chlamydial and yersinia elementary bodies were detected in affected joints. ${ }^{34}$ Our previous studies have clearly shown that $\mathrm{T}$ lymphocytes as immune effector cells are present in the synovial fluid. ${ }^{5}$

The existence of succeeding triggering infections able to cause a reactive joint inflammation in the same patient is a new finding. We found that reactive joint inflammation in complete remission could be triggered and reactivated by a quite different microbial antigen, causing fulminant relapsing reactive arthritis with all the characteristic symptoms.

It thus seems that the occurrence of inflammatory reactive complications is more dependent on the genetic constitution of the host than on the type of triggering infection. Furthermore, in this series the clinical picture differed between the two occasions, suggesting that factors other than heredity may play a part. Lastly, three of the five infections caused chronic arthritis after the second episode, possibly due to an amplified secondary autoaggressive immune response. Patients with reactive arthritis should therefore always be advised against exposure to enteral and venereal infections in order to prevent chronic arthritis from developing.

This study was supported by grants from Finska Läkaresällskapet, the Juselius Foundation, and the Oskar Öflund Foundation.

Clinical and serological data on the five patients and details of ensuing infections and time intervals between initial attack (I) and relapse (II) of complicating symptoms of arthritis

\begin{tabular}{|c|c|c|c|c|c|c|c|c|}
\hline $\begin{array}{l}\text { Case } \\
\text { No }\end{array}$ & $\begin{array}{r}\text { Sex a } \\
(y \\
\text { at } r\end{array}$ & $\begin{array}{l}\text { nd age } \\
\text { ears) } \\
\text { elapse }\end{array}$ & Triggering agent I/symptoms & Triggering agent II/symptoms & $\begin{array}{l}\text { Interval } \\
\text { before relapse } \\
\quad \text { (years) }\end{array}$ & $\begin{array}{l}\text { Rheumatoid factor/ } \\
\text { antinuclear antibody }\end{array}$ & $\begin{array}{l}\text { Sedimentation rate } \mathrm{I} / \\
\text { sedimentation rate II } \\
(\mathrm{mm} \text { in first hour })\end{array}$ & $x$ Ray findings $\mathrm{I} / x$ ray findings II \\
\hline 1 & M & 40 & $\begin{array}{l}\text { Yersinia enterocolitica } 1 / 1280 / \\
\text { oligoarthritis, iritis }\end{array}$ & $\begin{array}{l}\text { Chlamydia trachomatis } 1 / 128 \text { / } \\
\text { polyarthritis }\end{array}$ & 11 & Absent/absent & $64 / 43$ & $\begin{array}{l}\text { Normal/metatarsophalangeal } \\
\text { erosions }\end{array}$ \\
\hline 2 & M & 22 & $\begin{array}{l}\text { Salmonella verified serologically/ } \\
\text { monoarthritis in knee }\end{array}$ & $\begin{array}{l}\text { Yersinia enterocolitica } 1 / 5120 / \\
\text { oligoarthritis, conjunctivitis, } \\
\text { balanitis, urethritis }\end{array}$ & 6 & Absent/absent & $50 / 80$ & Normal/sacroiliitis \\
\hline 3 & $\mathrm{~F}$ & 32 & Yersinia enterocolitica $1 / 20480$ / & Salmonella $1 / 320$ polyarthritis, iritis & & & & \\
\hline 4 & $M$ & 39 & Neisseria gonorrhoeae verified & Salmonella (positive cultures)/ & & Absent/absent & $73 / 44$ & Normal/normal \\
\hline 5 & $\mathrm{M}$ & 21 & $\begin{array}{l}\text { serologically/monoarthritis } \\
\text { Salmonella } 1 / 320 \text { /monoarthritis in }\end{array}$ & $\begin{array}{l}\text { polyarthritis } \\
\text { Yersinia }\end{array}$ & 10 & Absent/absent & $\mathrm{ND} / 115$ & $\mathrm{ND} / \mathrm{ND}$ \\
\hline & & 21 & $\begin{array}{l}\text { Samonella } 1 / 320 / \text { monoarthritis in } \\
\text { knee }\end{array}$ & $\begin{array}{l}\text { Yersinia enterocoltica } 1 / 1280 / \\
\text { oligoarthritis }\end{array}$ & $1 \cdot 5$ & Absent/absent & $59 / 38$ & Normal/normal \\
\hline
\end{tabular}

